IZA DP No. 4438

Do Foreigners Replace Native Immigrants?

Evidence from a Panel Cointegration Analysis

Herbert Brücker

Stefano Fachin

Alessandra Venturini

September 2009 


\title{
Do Foreigners Replace Native Immigrants? Evidence from a Panel Cointegration Analysis
}

\author{
Herbert Brücker \\ Institute for Employment Research (IAB), \\ University of Bamberg and IZA \\ Stefano Fachin \\ University of Rome "La Sapienza" \\ Alessandra Venturini \\ University of Turin, \\ CHILD, RSCAS and IZA
}
Discussion Paper No. 4438
September 2009

\author{
IZA \\ P.O. Box 7240 \\ 53072 Bonn \\ Germany \\ Phone: +49-228-3894-0 \\ Fax: +49-228-3894-180 \\ E-mail: iza@iza.org
}

\begin{abstract}
Any opinions expressed here are those of the author(s) and not those of IZA. Research published in this series may include views on policy, but the institute itself takes no institutional policy positions.

The Institute for the Study of Labor (IZA) in Bonn is a local and virtual international research center and a place of communication between science, politics and business. IZA is an independent nonprofit organization supported by Deutsche Post Foundation. The center is associated with the University of Bonn and offers a stimulating research environment through its international network, workshops and conferences, data service, project support, research visits and doctoral program. IZA engages in (i) original and internationally competitive research in all fields of labor economics, (ii) development of policy concepts, and (iii) dissemination of research results and concepts to the interested public.
\end{abstract}

IZA Discussion Papers often represent preliminary work and are circulated to encourage discussion. Citation of such a paper should account for its provisional character. A revised version may be available directly from the author. 
IZA Discussion Paper No. 4438

September 2009

\section{ABSTRACT \\ Do Foreigners Replace Native Immigrants? Evidence from a Panel Cointegration Analysis}

This paper examines the impact of the immigration of foreigners on domestic labour mobility. Since David Card's seminal study on the regional labour market impact of the Mariel Boatlift it is controversial whether domestic labour mobility equilibrates economic conditions across cities and regions. However, there is little or no evidence that natives leave destinations where migrants tend to cluster. In this paper we reconcile the existing evidence by taking another route. We analyze whether the immigration of foreigners replaces domestic mobility from poor to rich regions. We focus on Italy, which is characterized by market differences in earnings between the North and the South. Based on a panel cointegration approach we exploit the variance of international and internal migration over time for identifying potential displacement effects. The main finding is that, conditional on unemployment and wage differentials, the share of foreign workers in the labour force of the destination regions discourages internal labour mobility significantly. As a consequence, spatial correlation studies which use the variance of the foreigner share across region for identifying the wage and employment effects of immigration, tend to understate the actual immigration impact.

JEL Classification: F22

Keywords: international migration, domestic migration, labour markets, panel cointegration, Italy

Corresponding author:

Alessandra Venturini

Department of Economics

University of Turin

Via Po, 53

10124 Torino

Italy

E-mail: alessandra.venturini@unito.it 


\section{Introduction ${ }^{1}$}

The objective of this paper is to contribute to a better understanding of the impact of international migration on domestic labour mobility in the destination country. We analyze the case of a destination country with a core and a periphery (two regions with cultural and geographical proximity but very distant in terms of factor endowment and of specialization patterns). The aim is to understand the role played by the inflow of foreign migrants in changing the equilibrium between labour markets in the two areas. The question we address is whether international migration - while mitigating an international imbalance - is aggravating a domestic imbalance in the countries of destination at the same time.

The literature on the effects of foreign immigration on native wages and employment opportunities has devoted much attention to the question whether the arrival of foreign immigrants has induced the out-migration of natives in the affected areas. Following David Card's famous analysis of the impact of the Mariel Boatlift on labour markets in the Miami region (Card, 1990), a large body of literature has exploited cross-regional differences in the foreigner share for identifying the effects of immigration on wages or other labour market variables. For an overview see Card (2002) and the references therein. Examples for European studies are Hunt (1992), Haisken-DeNew and Zimmermann (1999), Gavosto, Venturini and Villosio (1999) Winckelmann and Zimmermann (1993) and Dustmann (2005). ${ }^{2}$ Most of these studies find only weak effects if at all (see Longhi et al., 2005, 2006, 2008 , for a meta-analysis of the literature).

This literature has been challenged by the contributions of Filer (1992), Borjas (2003) and others, who suggest that the weak labour market effects of migration found in studies which use the cross-regional variation in the foreigner share might be traced back to the fact that natives leave areas where immigrants concentrate. Hence, the effects of migration are spread away to other areas and the impact of an increase in the foreign labour force in one area is diluted to other parts of the country. Borjas (2003) therefore proposes to use national data rather than regional data in order to identify the labour market effects of migration. Indeed, he finds evidence for larger effects of migration in national-level studies than those found in regional-level studies (Borjas, 2003; Aydemir and Borjas, 2006), although this evidence is not uncontroversial (see Ottaviano and Peri, 2006, 2008). However, as Card and Di Nardo (2000) and Card (2002) have shown, there is little or no evidence that natives do actually leave areas where international

\footnotetext{
${ }^{1}$ Financial support from MIUR is gratefully acknowledged. Thanks also to Monica Angelillo for skillful and dedicated research assistance and Roberto Quaranta for kindly providing data from the WHIP database. Correspondance to: Herbert.Bruecker@iab.de, s.fachin@caspur.it, alessandra.venturini@unito.it.

${ }^{2}$ For a careful survey of the European empirical results see also Venturini (2004).
} 
migrants cluster. Hence, there is no evidence which supports the hypothesis that regional-level studies tend to understate the impact foreign migration on domestic labour markets due to an out-migration of natives.

We reconcile this contrasting evidence in this paper by taking another route. Consider the case of a country which is characterized by a core and a periphery, i.e. by substantial differences in earnings and employment opportunities between the rich and the poor region. Distinguish three types of workers in the destination region by their migration status: local natives (born and resident there), immigrant natives (born in another region but resident in the core) and foreign immigrants. The entry of foreigners may indeed provide an incentive for natives in the destination region to move to another region of the core or even abroad if they compete in the labour market or other markets such as the housing market. However, since migrants from foreign countries usually tend to move into prosperous regions of the destination country, those incentives to leave an area penetrated by foreign migrants are relatively small. Moreover, foreign workers might be complements in the labour market for local natives or reduce prices for services and goods consumed by local natives.

There is however a second channel, by which foreign migration can affect the domestic labour supply: the entry of foreigners can replace immigration of natives from the periphery to the core. The entry of foreign migrants can hinder the immigration of natives from the periphery to the core by various channels: falling wages, lower employment opportunities, shortage of housing, and other effects which tend to replace domestic migration. Essentially, the negative effect of foreign immigration on native immigration can explain the reduction of native labour supply in regions where foreign migrants concentrate (in short, Borjas' hypothesis), which is however not induced by outflows of natives from the area of immigration (in short, Card's hypothesis).

Note that the out-migration of natives to other regions in the core and the replacement of immigration from the periphery to the core may cause different economic effects: while the first phenomenon restores an equilibrium between regions of the core after a labour supply shock, the latter conserves or even worsens imbalances between the periphery and the core.

To identify the different effects of international migration on domestic labour mobility, we analyze the impact of immigration of foreigners on native labour mobility. Contrary to the micro literature of the subject (Attanasio and Padoa Schioppa, 1991; Faini et al., 1997), which examines the effects of foreign immigration on the emigration of natives, we analyze here how foreign labour supply changes affect labour demand in the core, and, hence, native migration from the periphery to the core. For this purpose, we identify the basic channels by which foreign immigration can affect equilibria in the core and the periphery of the destination country in a simple labour market model which considers wage rigidities. Based on this model, we 
try to assess empirically whether the immigration of foreigners does indeed reduce domestic migration of natives from the periphery to the core.

Our empirical analysis focuses on Italy, which is in our view especially suitable for four reasons: First, Italy is characterized by marked regional differences in employment opportunities and wages between the core in the North and the periphery in the South. These regional imbalances are one of the largest within the EU and the OECD. Second, there exists a substantial amount of previous research which has examined the impact of immigration of foreigners on native wages (Gavosto et al. 1999) and on the probability of finding or losing a job (Venturini and Villosio, 2006). These studies have adopted the spatial correlation approach and find little or no evidence that foreign migration affects wages and employment opportunities of natives. Third, Italy has become one of the main destinations of immigration in Europe during the 1980s and 1990s, at a foreign population of 2 millions and a share of foreign workers in the Italian labour force of about $7 \%$ in 2007 . This share is increasing even further, making Italy together with Spain to one of the main migration destinations in Europe since the beginning of this century. Fourth, there exist long time-series data on foreign immigration as well as on domestic migration of natives in Italy, which enables us to address our empirical question within the framework of advanced time-series econometrics.

Our sample covers eleven destination regions in the Centre and North of Italy from 1975 to 2001. The empirical framework which we apply uses the variance of international and internal migration as well as of other key explanatory variables over time for identifying the potential replacement effects of foreign immigration. The variables of interest are very likely to be non-stationary. Although the econometric analysis of non-stationary variables is now two decades old and well established in the literature, the overwhelming share of the labour market literature on the determinants of migration ignores the time-series properties of the data (e.g. Clark et al., 2002; Hatton and Tani, 2002; Hatton, 2003; Pederson et al., 2003). Notable exceptions are the papers by Hatton (1995), Brücker and Schröder (2006) and Fachin (2007).

On the contrary, in this paper we fully take into account the stochastic properties of the variables of interest, as well as exploiting the panel structure of the data set. We take the cross-sectional dependence of the data into account by applying the cross-sectionally augmented ADF test proposed by Pesaran (2007) and the bootstrap panel cointegration test suggested by Fachin (2007). Although quite popular, we do not pool the data in the estimation of the model since pooled estimator are inconsistent if heterogeneity is present (see e.g. Pesaran and Smith, 1995). Allowing for full heterogeneity, we take into account the causal links between the variables of the model within each regional unit and between units of our panel.

Based on this approach, we find indeed evidence that foreign immigration 
replaces the internal migration of natives. Our estimation results suggest that these effects are significant and sizeable. Thus, the replacement of domestic migration is an important issue and has therefore to be considered in the analysis of the labour market effects of foreign immigration.

The remainder of the paper is organised as follows. Section 2 presents a simple model, which analyzes the wage and employment effects of migration in a core-periphery framework which considers the impact of migration on domestic labour mobility. Our model suggests not only that the immigration of foreigners replaces domestic labour mobility. Moreover, if domestic migration is indeed replaced by international migrants, the regional impact of foreign migration is mitigated such that regional-level studies find small or even no migration effects, even if they exist at the national level. Section 3 presents the data and Section 4 the empirical framework and and the estimation results. Section 5 concludes.

\section{Theoretical background}

\subsection{The impact of migration on labour supply}

Consider a country which comprises two regions, North and South. Labour is homogeneous, such that migrant and native workers are perfect substitutes. Wages and employment opportunities are better in the North, i.e. $w_{d}>w_{h}$, and $u_{d}<u_{h}$, where $w$ denotes the wage rate, $u$ the unemployment rate, and the subscript $d$ the North (i.e. the destination region) and the subscript $h$ the South (i.e. the home region of South-North migrants). Migrants move to region which is characterized by higher wages and better employment opportunities, i.e. the North.

The labour supply in the North is given by

$$
S_{d}=N_{d}+M_{d}+F_{d},
$$

where $S_{d}$ denotes the total labour force in the North, $N_{d}$ the labor force of local residents, $M_{d}$ the labour force from the South residing in the North, and $F_{d}$ the foreign labour force residing in the North. International migration is treated here as an exogenous shock. The labour supply of natives from the North is determined by the domestic migration equation

$$
N_{d}=a_{1}\left(\ln w_{d}-\ln w_{h}\right)-a_{2}\left(\ln u_{d}-\ln u_{h}\right)-a_{3} F_{d}+\boldsymbol{\delta}^{\prime} \mathbf{z}_{d},
$$

where the vector $\mathbf{z}_{d}$ denotes all location specific factors which influence domestic migration decisions of natives in the North such as a familiar environment and social relations, and $\delta$ the respective vector of coefficients. The third term on the right hand side captures all factors by which the presence 
of foreigners affect the utility of natives beyond wages and employment opportunities. This covers factors such as housing, congestion, criminality or simply xenophobia.

Analogously, the labour supply from the South in the North is represented by the migration equation

$$
M_{d}=b_{1}\left(\ln w_{d}-\ln w_{h}\right)-b_{2}\left(\ln u_{d}-\ln u_{h}\right)-b_{3} F_{d}+\boldsymbol{\lambda}^{\prime} \mathbf{z}_{d} .
$$

Equation (2) captures the traditional Borjas-Filer argument, although it has proven to be rather weak empirically according to the evidence provided by David Card. This is hardly surprising, since migrants tend to concentrate in prosperous regions, where the incentives for natives to leave are low. In contrast, equation (3) represents the argument which we will examine in this paper, i.e. that foreign migrants tend to replace the immigration of natives from other regions. However, the implications of pushing natives in away from the prosperous regions or replacing the immigration of natives from other regions are identical for the labour market, as is demonstrated in the next subsection.

\subsection{The labour market impact}

The marginal response of the labour supply in the North with respect to a marginal influx of migrants is given by

$$
\frac{d S_{d}}{d F_{d}}=\gamma_{1} \frac{d \ln w_{d}}{d F_{d}}-\gamma_{2} \frac{d \ln u_{d}}{d F_{d}}-\left(1-\gamma_{3}\right),
$$

where we use $\gamma_{1}=a_{1}+b_{1}, \gamma_{2}=a_{2}+b_{2}$, and $\gamma_{3}=a_{3}+b_{3}$, for convenience. Note that Equation (4) implies that we ignore the indirect effects of migration into the North on wages and employment opportunities in the South. This can be justified by the assumption that migration is small or that the North is a small region relative to the South.

For the analysis of the wage and employment impact of migration it is necessary to make assumptions on the wage setting mechanism. We assume here that wages are fixed by a bilateral bargaining monopoly between trade unions and employer federations. The employer hires workers until the wage equals the marginal productivity of labour when the wage is fixed ('right-to-manage'). This is known by the participants in the wage negotiations. The participants consider the impact of wages on (un-)employment, albeit imperfectly. This allows writing the wage rate as a function of the unemployment rate, i.e. as

$$
w_{d}=\phi\left(u_{d}\right)
$$

where $\phi^{\prime}<0$ and the unemployment rate is defined as

$$
u_{d}=1-\frac{L_{d}}{S_{d}} .
$$


We assume furthermore that the aggregate production function of the region is characterized by constant returns to scale and homogeneous of degree 1. In the short term, the capital stock is fixed. This enables us to derive the implicit function

$$
\Phi\left(L_{d}, S_{d}\right) \equiv w_{d}\left(L_{d}\right)-\phi\left(u_{d}\left(L_{d}, S_{d}\right)\right)=0,
$$

where the wage rate $w_{d}$ equals the marginal product of labour and $\phi$ is by the definition of the unemployment rate a function of $L_{d}$ and $S_{d}$.

For convenience, we write in the following the elasticity of the wage rate with respect to labour as $\alpha$ and the semi-elasticity of the wage with respect to unemployment as $\eta=-\phi^{\prime} / w_{d}$. Differentiating equation (6) implicitly yields then the marginal response of employment with respect to the immigration of foreign workers:

$$
\begin{aligned}
\frac{d L_{d}}{d F_{d}} & =\frac{\eta\left(1-u_{d}\right)^{2}}{\eta\left(1-u_{d}\right)-\alpha} \frac{d S_{d}}{d F}, \\
& =\frac{\left(1-\gamma_{3}\right) \eta\left(1-u_{d}\right)^{2} S_{d}}{\left[\eta\left(1-u_{d}\right)-\alpha\right] S_{d}-\alpha\left(1-u_{d}\right)\left[\gamma_{1} \eta+\gamma_{2} / u_{d}\right]} .
\end{aligned}
$$

The marginal impact of migration on employment reduces to the expression

$$
\frac{d L_{d}}{d F_{d}}=\frac{\eta\left(1-u_{d}\right)^{2}}{\eta\left(1-u_{d}\right)-\alpha}
$$

if migration does not affect internal labour mobility, i.e. if $\gamma_{i}=0, \forall i$, and $i$ $\in\{1,2,3\}$. Thus, the impact of migration on the growth of employment is smaller if migration has no impact on domestic labour mobility (note that $\alpha$ is negative). by

The marginal impact of migration on the wage rate in the North is given

$$
\frac{d w_{d}}{d F}=\frac{\left(1-\gamma_{3}\right) \alpha \eta\left(1-u_{d}\right) w_{d}}{\left[\eta\left(1-u_{d}\right)-\alpha\right] S_{d}-\alpha\left(1-u_{d}\right)\left[\gamma_{1} \eta-\gamma_{2} / u_{d}\right]},
$$

which is smaller than the impact in case of no domestic labour mobility, i.e. smaller than

$$
\frac{d L_{d}}{d F_{d}}=\frac{\alpha \eta\left(1-u_{d}\right) w_{d}}{\eta\left(1-u_{d}\right)-\alpha} .
$$

Finally, the impact of immigration on the unemployment rate in the North is given by

$$
\frac{d u_{d}}{d F_{d}}=\frac{-\alpha\left(1-\gamma_{3}\right)\left(1-u_{d}\right)}{\left[\eta\left(1-u_{d}\right)-\alpha\right] S_{d}-\alpha\left(1-u_{d}\right)\left[\gamma_{1} \eta+\gamma_{2} / u_{d}\right]},
$$

which reduces to

$$
\frac{d w_{d}}{d F_{d}}=\frac{-\alpha\left(1-u_{d}\right)}{\left[\eta\left(1-u_{d}\right)-\alpha\right] S_{d}}
$$


in case of no domestic labour mobility. Note again that $\alpha$ is negative such that an increase in labour supply through immigration increases unemployment in the destination region. Nevertheless, internal labour mobility dilutes the effects of immigration on unemployment in the destination region.

\subsection{Transfers to the South}

In Italy migration incentives are diminished by substantial fiscal transfers from the wealthy North to the less prosperous South. Assume for the sake of convenience that transfers are financed by a proportional tax on labour income and take the form of direct payments. We can then rewrite equations (2) and (3) as

$$
\begin{aligned}
N_{d} & =a_{1} \ln \left((1-\tau) w_{d}\right)-\ln \left((1-\tau) w_{h}\right)-a_{2}\left(\ln u_{d}-\ln u_{h}\right) \\
& -a_{3} F_{d}+a_{4} \ln \pi_{h}+\boldsymbol{\delta}^{\prime} \mathbf{z}_{d}
\end{aligned}
$$

and

$$
\begin{aligned}
M_{d} & =b_{1} \ln \left((1-\tau) w_{d}\right)-\ln \left((1-\tau) w_{h}\right)-b_{2}\left(\ln u_{d}-\ln u_{h}\right) \\
& -b_{3} F_{d}+b_{4} \ln \pi_{h}+\boldsymbol{\lambda}^{\prime} \mathbf{z}_{d}
\end{aligned}
$$

where $0 \leq \tau \leq 1$ denotes the proportional tax on labour income and $\pi_{h}>0$ the transfer payment per capita which each member of the labour force receives in the South. Note that $\pi_{h}=\tau\left[w_{d}\left(1-u_{d}\right) s_{d}+w_{h}\left(1-u_{h}\right)\right]$, where $s_{d}$ denotes the ratio of the labour force in the North to the labour force in the South, i.e. $s_{d}=S_{d} / S_{h}$. Fiscal transfers thus reduce the incentives for natives from the South to move to the North, while it increases the incentives for natives from the North to move to the South.

\subsection{Specification of the empirical model}

Consider the partial adjustment mechanism $\Delta M_{d h, t}=\theta\left(M_{d h, t}^{*}-M_{d h, t-1}\right)$, where $M_{d h, t}^{*}$ is the long-run equilibrium stock of natives natives from the home region $h$ at destination $d$ as given by equation (3), and the parameter $\theta(0<\theta<1)$ determines the speed of adjustment. If we normalize the migration stock by the labour force in the destination region and by adding an error term yields the estimation equation

$$
\begin{aligned}
m_{d h t} & =\beta_{0}+\beta_{1}\left(\ln w_{d t}-\ln w_{h t}\right)+\beta_{2}\left(\ln u_{d t}-\ln u_{h t}\right)+\beta_{3} f_{d t}+\beta_{4} \ln \pi_{h t} \\
& +\beta_{5} m s t_{d h, t-1}+\varepsilon_{d h t},
\end{aligned}
$$

where the migration rate $m_{d h t}$ is defined here as $\Delta M_{d h t} / S_{d t}, f_{d t}$ as $F_{d t} / S_{d t}$ and $m s t_{d h, t-1}$ as the normalized lagged migration stock, i.e. as $M_{d h, t-1} / S_{d, t-1}$. $\beta_{0}$ denotes the constant, $\beta_{i}(i \in 1,2 \ldots 5)$ the coefficients for the explanatory variables, and $\varepsilon_{d h t}$ the error term. Note that we have assumed that the 
(net) migration inflow equals the change in the migration stock, i.e. we have ignored differences in the natural rate of population growth between natives from the South residing in the North and the native population in the South.

Following our theoretical considerations, we expect that $\beta_{1}>0, \beta_{2}<$ $0, \beta_{3}<0, \beta_{4}<0$ and $\beta_{5}<0$. The negative coefficient for the lagged migration stock follows from the partial adjustment mechanism, i.e. from the assumption that $\gamma>0$. However, network effects or chain migration effects which tend to reduce information and search costs as well as the costs of living in an unfamiliar environment, are positively correlated with lagged migration stocks. Thus, the impact of the lagged migration stock on the migration rate might be ambiguous. We assume here nevertheless that the negative effect of the lagged migration stock dominates the positive impact of network and chain effects at least in the long-run, since any dynamic migration model would result in the total emigration of the population from sending regions if otherwise.

The analysis of domestic migration is hindered by serious data problems. Data on migration stocks of natives residing in other regions are usually not available, nor are return migration rates. Our analysis relies therefore on variables which are in our view good proxies for the variables of the model in equation (12). We approximate therefore the change in migration stocks (i.e. the net migration rate) by the gross migration rate, which is closely correlated to the net migration rate. Moreover, we furthermore approximate the lagged migration stock by the cumulative gross migration rate (hereafter in short "migration chain") during the last three years. The model that we estimate here is thus similar but different to the traditional Borjas-CardFiler (alphabetic order adopted) approach, which assumes that natives in destination countries react to foreign immigration. We do not deny the possible effect of foreign immigration on the mobility of the natives. However, since the evidence that natives are pushed away from prosperous regions in the core where foreign migrants tend to concentrate is rather weak, we focus here on the effect of foreign immigrants on native immigration from the periphery.

\section{International immigration and internal migra- tion in Italy}

Although Italy's long tradition of international and internal migration is well known, ${ }^{3}$ its recent experience of massive immigration is much less studied.

\footnotetext{
${ }^{3}$ Both Northern and Southern Italy were origin of important migration flows to Northern and Southern America and Northern Europe from the end of the 19th century until the 1960s. During the 1960s and the 1970s, internal migration from the largely rural South to the industrialized North-West Italy and Rome (which is in the Center of the country)
} 


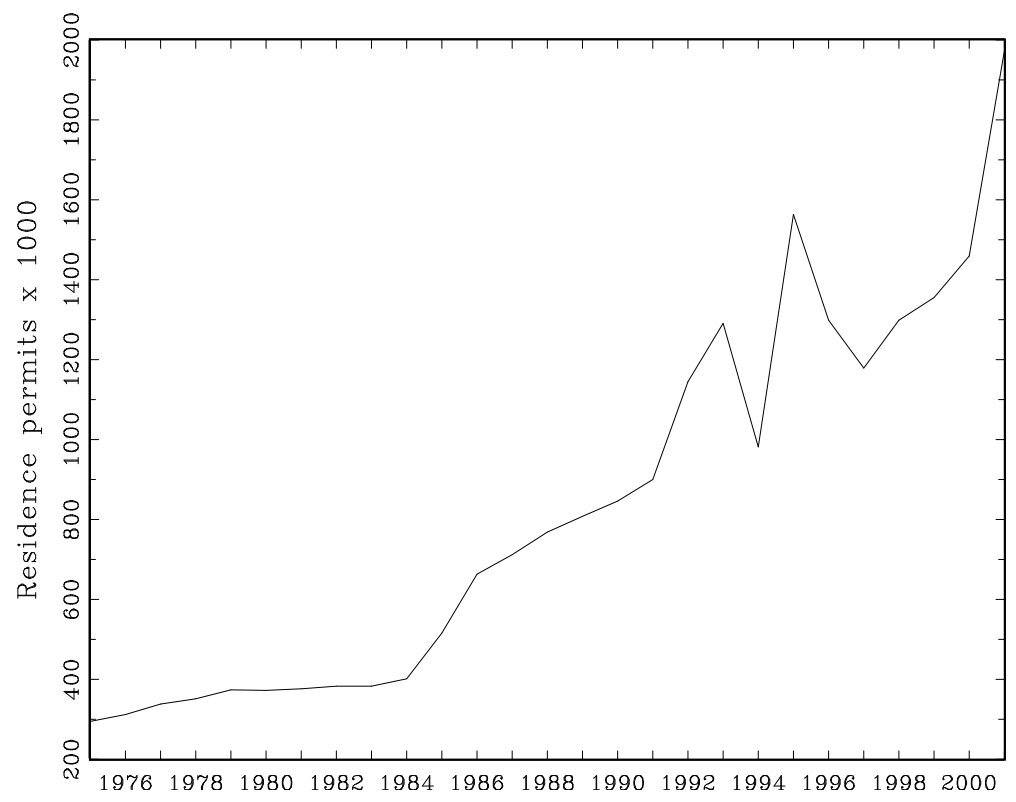

Figure 1: Residence permits in Italy, 1975-2001 (thousands) Notes: Data before 1992 refer to gross permits (incl. expired permits). Source: Ministry of the Interior.

Migrants started to choose Italy as a destination country by the end of the 1970s. These early flows originated mainly in the Mediterranean Northern African countries (Morocco, Tunisia), the former Italian East Africa colonies (Ethiopia and Eritrea) and the Philippines. These inflows, and, as a consequence, the stocks of foreign workers, became increasingly important in the following decades (see Table 1 and Figure 1). Migration to Italy was further boosted by the collapse of the Communist regimes in Central and Eastern Europe. Since the beginning of the 1990s, large immigration flows stem from countries such as Albania, Romania and Moldova (very close respectively in geographical and language terms), but Poland and Ukraine (definitely more distant according to either measure) have also sent a considerable number of migrants.

The overwhelming share of foreign workers holds unskilled positions (men typically in the construction and in the industrial sector, while women in the service sector or as housekeepers and babysitters) (Eurostat 2008). Immigrants entered the country often illegally and obtained regular residence permits later on as a result of one of the many amnesties granted by the Italian Government during the period considered in this study. Since one of the conditions to qualify for a residence permit is to hold a regular job, many of the immigrants entered the country illegally crossing the Mediterranean

was also massive. For a survey see Del Boca and Venturini (2005). 
from the Northern African coasts to the close Southern Italian regions ${ }^{4}$, and then moved to the more industrialized regions in the North of Italy. According to the 2001 Population Census, $61.8 \%$ of the foreign nationals in Italy reside in the North, $25 \%$ in the Center, and only $13.2 \%$ in the South. As mentioned already, internal migration in Italy has typically been taking place from the depressed South to the more advanced part of the country, the Centre-North. In our empirical analysis we shall thus concentrate on this part of the country, dividing it into 11 regions: ten NUTS 2 areas (regioni, hereafter regions) plus the aggregate of the two neighbouring NUTS 2 regions Piedmont and Val d'Aosta. The latter, though a NUTS 2 area, with less than 61.000 residents according to the 2001 Population Census is far too small to be the object of an independent robust empirical analysis. For descriptive purposes we will sometimes cluster these regions in three or four groups:

1. North-West (NW): Piedmont-Val d'Aosta, Liguria and Lombardia.

2. North-East (NE): Trentino-Alto Adige, Friuli-Venezia Giulia, Veneto and Emilia-Romagna. According to the different geographical characteristics, which induce a different urban structure, we can further distinguish the first two (hereafter North-East/Alps), which include mostly mountain areas, from the remaining (hereafter North-East/Po, as they lie in the Po river valley), which include mostly plains.

3. Center: Umbria, Marche, Tuscany and Lazio.

The total stocks of the residency permits granted to males in the 2064 cohort in these 11 regions of Central-Northern Italy are plotted in Fig. 2. Note that these series are gross of expired permits until 1991 and net afterwards: this causes some large breaks in 1992. As we can see, taking into account this change in definition ${ }^{5}$ the trends are all largely positive. At the end of the 1990's the largest stocks of foreign workers in proportion of the labour force was found in the North-East/Alps (almost 14\%; see Table 1). The presence is more limited in the Center (7\%), North-West $(5 \%)$ and North-East/Po (3\%). On the contrary, immigration flows from the South ${ }^{6}$ have declined since the mid-1990s in all destination regions with the exception of the Center, where they increased marginally. The fall is particularly noticeable in the North-East, where it followed a comparably large hump in the first half of the 1990's.

\footnotetext{
${ }^{4}$ Abruzzo, Molise, Campania, Basilicata, Puglia, Calabria, Sicily and Sardinia.

${ }^{5}$ In the modelling section we shall correct the variable for this break with a non parametric smoothing procedure (more details are given in the Data Appendix). Here we preferred to use the raw data.

${ }^{6}$ Separate analyses for different parts of the South, e.g. South-East and South-West, are left to future research.
} 


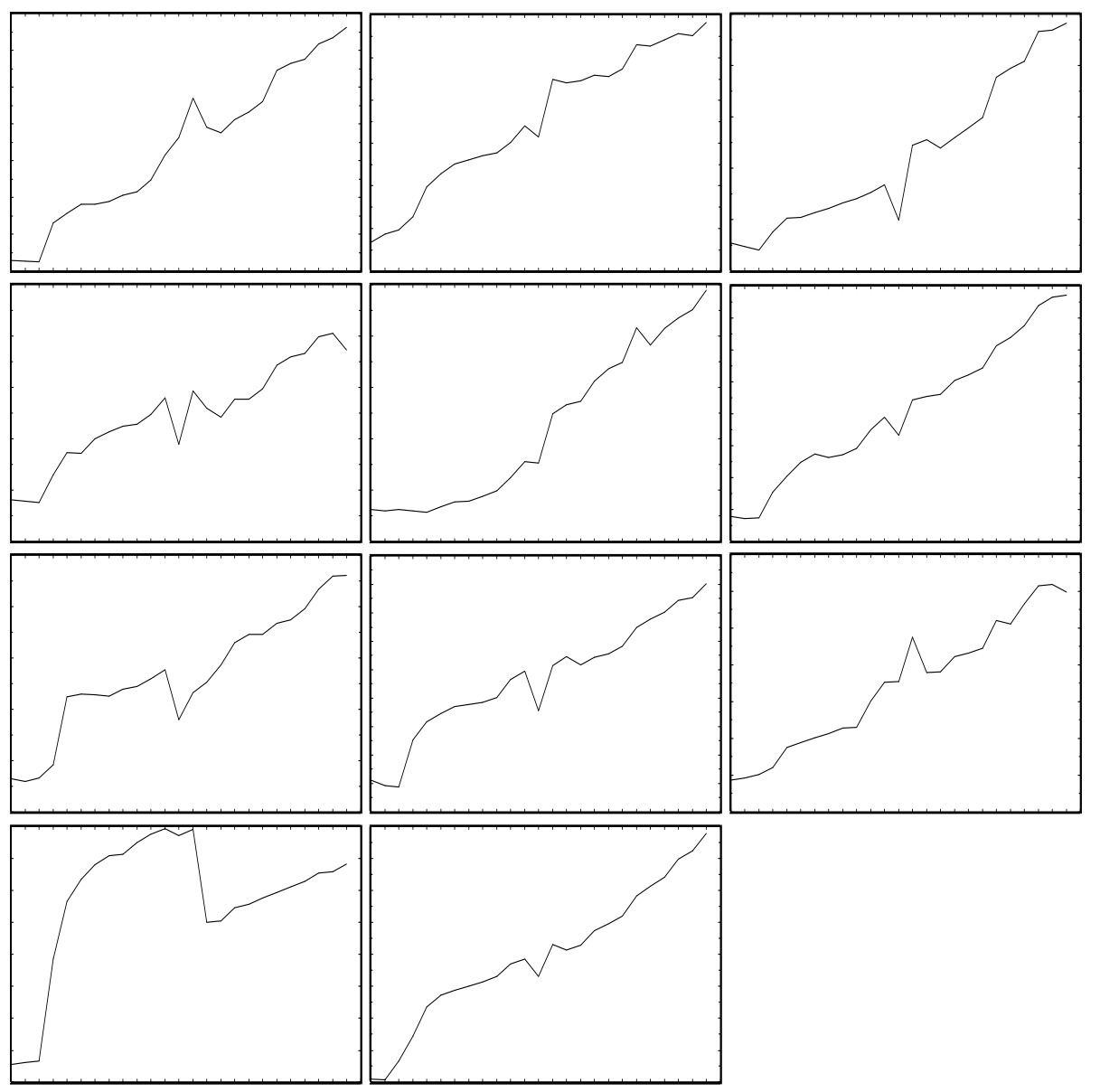

Figure 2: Residence permits in Italian Central-Northern regions as a share of the labour force (logarithmic scale), 1975-2001 Notes: Data before 1992 include expired permits. Source: Ministry of the Interior and Istat (left to right and top to bottom: Piedmont and Val d'Aosta, Lombardia, TrentinoAlto Adige; Veneto, Friuli-Venezia Giulia, Liguria; Emilia-Romagna, Tuscany, Umbria; Marche, Lazio) 
As Table 2 shows, differences in unemployment rates between the South and the Northern and - to a lesser extent - the Central regions are more likely to explain internal migration incentives than wage differences, which have been very small during the entire sample period. In fact, in the main destination area, the North-Eastern/Alp regions, the wage rate was generally close to, or even slightly smaller than, that of the Southern regions. Conversely, since the mid-1980s the low or moderate unemployment rates in the Center-North have been in striking contrast with the mass unemployment in the South. Within the destination areas there have been some significant differentials, though: the North West, traditionally the most developed area of the country, experienced a rather long stagnation in the 1980s and 1990s. As a consequence, its unemployment rate has been a few points higher there than that in the North East where it has declined steadily since the mid 1980s. In the Center regions, labour market conditions have been always distinctly worse than that in all Northern areas, though obviously still much better than in the South during the period of interest.

Table 1

Foreign and native immigration in the regions of Central and Northern Italy, 1975-2001

\begin{tabular}{|c|c|c|c|c|}
\hline & $\overline{\mathrm{NW}}$ & $\mathrm{Po}$ & NE/Alps & Center \\
\hline \multicolumn{5}{|c|}{ Stock of foreign residents } \\
\hline \multicolumn{5}{|c|}{ (\% of the labour force) } \\
\hline $1975-1980$ & 1.0 & 0.5 & 2.5 & 1.9 \\
\hline $1981-1985$ & 1.4 & 0.7 & 3.4 & 2.9 \\
\hline $1986-1990$ & 1.8 & 1.1 & 5.1 & 4.5 \\
\hline $1991-1995$ & 2.8 & 1.7 & 7.5 & 5.2 \\
\hline $1996-2001$ & 5.2 & 3.1 & 13.7 & 7.3 \\
\hline \multicolumn{5}{|c|}{$\begin{array}{c}\text { Immigration flows from Southern regions } \\
\text { (\% of the labour force) }\end{array}$} \\
\hline $1975-1980$ & 1.8 & 2.8 & 7.9 & 10.0 \\
\hline $1981-1985$ & 2.5 & 2.0 & 12.0 & 2.3 \\
\hline $1986-1990$ & 2.8 & 3.1 & 8.7 & 4.1 \\
\hline $1991-1995$ & 2.3 & 4.0 & 20.0 & 4.2 \\
\hline $1996-2001$ & 1.6 & 1.4 & 6.2 & 5.2 \\
\hline \multicolumn{5}{|c|}{$\begin{array}{l}\text { Foreign residents: total; } \\
\text { Native immigration flows: males, 20-64; } \\
\text { Southern regions: Abruzzo, Molise, Campania, } \\
\text { Basilicata, Puglia, Calabria, Sicily, Sardinia. } \\
\text { Data sources: Ministry of the Interior and Istat. }\end{array}$} \\
\hline
\end{tabular}


Table 2

Unemployment and wages in Italy, 1975-2001

\begin{tabular}{rrrrrr}
\hline \hline & NW & NE/Po & NE/Alps & Center & South \\
\hline \multicolumn{5}{c}{ Unemployment rate (\%) } \\
\hline $1975-1980$ & 4.1 & 4.4 & 3.3 & 6.2 & 8.8 \\
$1981-1985$ & 6.7 & 7.2 & 6.4 & 8.6 & 13.5 \\
$1986-1990$ & 7.6 & 7.2 & 7.3 & 9.9 & 19.4 \\
$1991-1995$ & 6.2 & 5.3 & 5.2 & 9.5 & 19.4 \\
$1996-2001$ & 6.3 & 4.8 & 4.7 & 9.2 & 21.2 \\
\hline \multicolumn{5}{c}{ Annual wage (Lira, million) } \\
\hline $1975-1980$ & 6.7 & 6.4 & 6.2 & 6.6 & 6.5 \\
$1981-1985$ & 15.9 & 15.4 & 15.0 & 15.9 & 15.3 \\
$1986-1990$ & 25.2 & 24.3 & 23.7 & 25.0 & 23.8 \\
$1991-1995$ & 35.0 & 33.9 & 33.1 & 34.9 & 33.0 \\
$1996-2001$ & 40.2 & 38.7 & 38.1 & 39.3 & 36.4 \\
\hline \hline
\end{tabular}

Wage: 1936.72 Lire $=1$ Euro.

Data sources: Istat and National Social Security

Institute (INPS).

\section{Empirical method and estimation}

\subsection{Outline of the testing and estimation strategy}

As already discussed above, the key point to be taken in to account in the specification of the empirical model is that the variables involved are very likely to be non-stationary. In order this issue we have to $(i)$ examine carefully the stochastic properties of variables of interest, (ii) test for the existence of a long-run equilibrium relationship (or cointegrating relationship) between them, and, if this relationship holds, (iii) estimate the model by using some suitable method. Let us discuss these three points in turn.

First, testing for non-stationarity and for cointegration $(i-i i)$ requires special care, as both unit-root and cointegration tests are well known to have low power in samples as small as ours (26 observations). Hence, we may fail to detect an existing equilibrium relationship simply because of insufficient information. Fortunately, our data can be naturally seen as a panel, where the units are the different destinations. Exploiting this feature we will be able to run testing procedures more powerful than traditional time series ones. However, these panel tests also have to be chosen carefully because our units are dependent ${ }^{7}$. This feature is not admitted by most of the panel tests available, such as the IPS test (Im, Pesaran and Shin,

\footnotetext{
${ }^{7}$ In fact, perfectly dependent in the case of the cointegration tests, since the home consumption variable is the same for all units.
} 
2003) often used in applied work. We will thus use the cross-sectionally augmented ADF panel unit root test (CIPS) proposed by Pesaran (2007) and the bootstrap panel cointegration test developed by Fachin (2007), both robust to dependence and able to deliver good small sample results.

Second, we have to consider several aspects in the estimation of the model. A first point is the pooling issue. Seeing the data as a non-stationary panel we may either allow for full heterogeneity and, hence, estimate separate equations for each destination, or impose homogeneity by pooling the data. The latter option, through empirically popular, is potentially troublesome, as pooled estimators are not consistent under heterogeneity (for the OLS case, see Pesaran and Smith, 1995). We excluded this option, since it is estremely unlikely that the slope coefficients are the same for all destination regions.

Allowing for full heterogeneity, the complete Data Generating Process (DGP) has one equation for each variable (dependent and explanatory) in each unit of our panel set-up. We thus have to take into account the structure of the links both between variables within each unit and between units. The former is particularly important, as there are two potential causes of endogeneity of the right-hand side variable:

(i) innovations of the dependent variable Granger-causing those of the right-hand side variables;

(ii) the long-run disequilibrium in the dependent variable entering the DGP of the right-hand side variable.

In our case both effects are especially plausible for the share of foreign workers in the Center-North. On one hand, this variable may receive a positive (negative) shock from a negative (positive) internal migration shock. On the other, deviations of the share of migrants from the South from its long-run equilibrium level can affect foreign immigration (e.g., foreign immigration may be fostered by insufficient internal mobility).

Endogeneity of type $(i)$ has serious effects on the properties of standard OLS estimators, but it is not an issue for more general estimators such as the FM-OLS estimator (Phillips and Hansen, 1990). It is more complex to address deviations of the internal immigration variable from its long-run eequilibrium. If the disequilibrium in the dependent variable enters the DGP of one of the explanatory variables this variable is not weakly exogenous any more, and asymptotic inference on single-equation estimators is not valid. As a consequence, full-information system estimation is required (e.g., the FIML estimator which has been developed by Groen and Kleibergen, 2003, for a panel set-up). Unfortunately this is not feasible here given the small time dimension of our sample. Hence, we proceed with limited-information estimation of the conditional equations relating internal migration to the set 
of explanatory variables discussed previously and test whether the foreign immigration variable is weakly exogenous in the long-run.

The second category of cross-equation links mentioned above is between units, which in our case are the different destination regions. The problem we have to address here is that the shocks of equations for different destinations are very likely to be correlated, which in principle would call for SUR estimation to increase efficiency. In practice, this is not advisable in case of our data: since the time dimension of our sample is only marginally larger than the cross-sectional dimension, the estimates of the long-run covariance matrix will be of very poor quality or even impossible to obtain (Pedroni, 1997, Di Iorio and Fachin, 2008). We apply therefore a standard single-equation method.

Summing up, assuming that Pesaran's CIPS test will prove that our data are non-stationary, our further empirical analysis will follow an iterative twostep procedure:

Step A - Panel Cointegration test: First, we compute the ADF cointegration test statistic for equation (12) in each single destination; second, we carry out the bootstrap panel cointegration tests proposed by Fachin (2007) based on the mean and median of these ADF statistics.

Step B - Estimation: We estimate equations (12) by FM-OLS thereby testing the share of foreign workers for weak exogeneity.

If the estimation results under step B suggest that some coefficient should be constrained to zero step $\mathrm{A}$ is repeated on the constrained specification of the model, until a satisfactory specification is achieved.

\subsection{Testing for non-stationarity}

Let us now start the empirical analysis by examining the stochastic properties of our variables. The null hypothesis is that all variables of the model are characterized by a single unit-root except the share of foreign workers in the labour force of the destination region. The latter variable, being a function of the sum of past net immigration flows, is expected to be integrated of second order. For this series we thus start testing the null hypothesis of I(2)-ness following Dickey and Pantula (1987).

Log wage and unemployment differentials are trend stationary if either $(i)$ the two series involved are trend stationary $(T S)$ with different slopes, or $(i)$ they are cointegrated with a unit coefficient and have different drift terms. Hence, in these cases the order of the deterministic kernel has been determined by Ayat and Burridge's (2000) sequential procedure, which implies that we include a trend whenever significant. In all migration variables the trend was excluded a priori. 
Let us first discuss the results of the tests of $H_{0}: I(1)$ hypothesis, namely those for the log unemployment and wage differentials, the migration chain (past migration - Pm) and the native migration flows divided by the destination labour force. The migration chain is measured by the sum of the total (male and female) flows of the previous three years divided by the current labour force.

Overall, the results of the ADF tests (reported in Table 3) for the log unemployment and wage differentials are largely in favour of the hypothesis of difference stationarity. At the $1 \%$ level this is rejected in favour of the trend stationarity alternative only in the case of the log unemployment differential in Friuli-Venezia Giulia and the log wage differential in Umbria and Lazio; in a couple of more cases it is rejected at the $5 \%$ level, mostly in favour of the $T S$ alternative. The migration chain variable appears largely differencestationary for the northern regions but strongly stationary in those of the Center. Finally, the internal migration rate is mostly, but not always, difference stationary. The null hypothesis is rejected in favour of the alternative of stationarity (without a deterministic trend) in the case of Lombardia and Trentino-Alto Adige. Looking at the plots (Fig. 3) the outcome for these two regions appears puzzling; it is probably determined by a pattern followed in only a part of the time sample.

Finally, according to our individual tests the share of foreigners in the labour force is mostly $\mathrm{I}(2)$, but this finding is reverted by the CIPS panel test, which rejects the null hypothesis. This happens also for the log wage differential, where the mean ADF is heavily influenced by few large values (especially Lazio), and the migration chain variable, which is strongly stationary in the four Central regions. 
Table 3

Unit Roots Tests, $1975-2001$

\begin{tabular}{|c|c|c|c|c|c|}
\hline \multicolumn{6}{|c|}{$\mathrm{ADF}$} \\
\hline & $u^{d}$ & $w^{d}$ & $f$ & $P m$ & $m$ \\
\hline Piemonte-Val d'Aosta & $-3.77^{T * *}$ & $-2.09^{T}$ & $-2.78^{*}$ & -2.57 & -2.44 \\
\hline Lombardia & $-3.42^{T *}$ & $-2.92^{T}$ & -1.31 & -2.54 & $-3.44^{* *}$ \\
\hline Trentino-Alto Adige & $-0.72^{C}$ & $-0.06^{T}$ & $-3.42^{* *}$ & -2.53 & $-3.12^{* *}$ \\
\hline Veneto & $-2.82^{T}$ & $-0.53^{T}$ & -1.59 & -2.14 & -1.92 \\
\hline Friuli-Venezia Giulia & $-5.46^{T * * *}$ & $-2.11^{T}$ & -2.12 & -2.12 & -1.99 \\
\hline Liguria & $-0.80^{C}$ & $-3.66^{C * *}$ & -2.23 & -2.45 & -0.32 \\
\hline Emilia-Romagna & $-2.56^{T}$ & $-2.98^{T}$ & -2.21 & -2.76 & -0.25 \\
\hline Toscana & $-2.31^{T}$ & $-0.26^{T}$ & -2.48 & $-3.78^{* * *}$ & $-3.82^{* * *}$ \\
\hline Umbria & $-2.02^{T}$ & $-4.45^{T * * *}$ & $-3.35^{* *}$ & $-4.47^{* * *}$ & -1.33 \\
\hline Marche & $-2.58^{T}$ & $-2.93^{T}$ & -1.52 & $-3.67^{* *}$ & -0.04 \\
\hline Lazio & $-2.77^{C}$ & $-8.20^{T * * *}$ & -1.69 & $-3.49^{* *}$ & $-2.79^{*}$ \\
\hline \multicolumn{6}{|c|}{ CIPS } \\
\hline with constant & -2.19 & $-3.16^{* * *}$ & $-2.29^{*}$ & $2.85^{* * *}$ & -0.90 \\
\hline with constant and trend & $-2.93^{* *}$ & $-3.31^{* * *}$ & - & - & - \\
\hline $\begin{array}{l}u^{d}: \log \text { unemployment } \\
w^{d}: \log \text { wage differentia } \\
f: \log \text { share of foreign } \\
P m: \text { migration chain; } \\
m: \log \text { share of native in } \\
\text { force; } H_{0}: I(1) ; \\
C: \text { Constant included, } \\
\text { (trend never included fo } \\
C I P S: \text { Pesaran }(2007) \\
*, * *, * * * \text { significant at } 10 \\
\text { Lag selection: } 10 \% t \text {-tes }\end{array}$ & $\begin{array}{l}\text { fferential; } H \\
H_{0}: I(1) ; \\
\text { rkers on lak } \\
: I(1) ; \\
\text { migrants fro } \\
\text { Constant a } \\
f, c \text { and } m)\end{array}$ & $\begin{array}{l}\text { : } I(1) \\
\text { our force of } \\
\text { m the South } \\
\text { Trend inc }\end{array}$ & $\begin{array}{l}\text { destinatio } \\
\text { in the de } \\
\text { luded, }\end{array}$ & n area; $H_{0}$ & $I(2)$; \\
\hline
\end{tabular}




\subsection{Cointegration: Estimation and Testing}

Given the somewhat contradictory results of the unit-root tests presented in the previous section we decided not to drop any variable in the first estimation step. Instead we start with the full specification (12) and use the findings obtained there as a priori in the model selection phase. In view the small time dimension of the sample we have to be especially careful here: although the cointegrating coefficients of unrelated variables eventually converge to zero, in small samples they can be very far from it. Hence, redundant variables may obscure existing cointegrating relationships ${ }^{8}$. The solution suggested by Fachin (2007) is to select the final specifications from general ones excluding variables with very small or wrongly signed coefficients, which may suggest spurious relations. A fall in the $p$-value of the (no) cointegration statistic will confirm that these variables have indeed to be excluded.

Let us now move to the cointegration test results. The panel cointegration tests with the fully heterogenous specification (fixed effects and heterogenous slopes) are reported in Table $4 \mathrm{~A}$, along with the $p$-values of three versions of bootstrap tests results: the simple and corrected $p$-values using the Davidson and MacKinnon's (2000) Fast Double Bootstrap Type 1 and Type 2 test (the latter reliable only if consistent with the former). The bootstrap algorithm used 1000 redrawings and a block length fixed at 4 . Note that some experiments show that the results are rather robust to the choice of the latter within a reasonable range. The FM-OLS estimation results of the individual equations, individual cointegration test and the t-test for long-run weak exogeneity of the share of foreign workers are reported in Table 4B.

As to be expected in view of the small sample size, no individual cointegration statistcs $\left(Z_{\alpha}\right.$, last column) is significant. The average of the individual ADF cointegration statistics is not significant either (the Group $t$-statistic is -3.8 , with the various bootstrap $p$-values between $32 \%$ and $43 \%$ ). However, the median of the test statistics is closer to the critical region: the value is -4.6 , with $p$-values between $9 \%$ and $15 \%$. In both cases the Fast Double Bootstrap $p$-values are alweays reasonably close to each other and to those delivered by the standard bootstrap, suggesting that the latter is reliable. As also to be expected, many coefficients are small compared to their estimated variance or have wrong signs. In particular, the share of foreign workers in the labour force has the expected negative impact and well-defined coefficients in six cases. In the remaining five equations the coefficient is instead positive, a hardly meaningful result. In two cases (Trentino-Alto Adige and Friuli-Venezia Giulia) the coefficients are

\footnotetext{
${ }^{8}$ Let $y_{t}=\beta x_{t}+\varepsilon_{t}$ be a cointegrating relationship, so that $\varepsilon_{t}$ is stationary. Consider the model $y_{t}=b x_{t}+g z_{t}+e_{t}$, where $z$ is an unrelated $\mathrm{I}(1)$ variable. It is immediate to see that $e_{t}=\varepsilon_{t}-g z_{t}$, which is $\mathrm{I}(1)$ if $g \neq 0$.
} 
not significant, so the variable may be simply dropped from the specification. In the remaining three they are significant, so that we apparently have a problem. Before proceeding any further we should however recall that, as discussed above, it is important to check whether the share of foreign workers is weakly exogenous in the long-run: if this is not the case the estimates are biased and the $t$-statistics follows a skewed and non-central distribution. As a consequence, the significance tests will be biased against the null hypothesis (Boswijk, 1995). In other words, if the share of foreign workers si not weakly exogenous the coefficients may be spuriously significant. Following Boswijk (1992) we test weak exogeneity computing a significance test for the residuals of the cointegrating equations in a marginal model of the variable of interest, the log difference of the share of foreign workers. The test results are reported in column $W_{f}$ of Table $4 \mathrm{~B}$. We can first of all see that when the coefficient has the expcted negative sign the test is, often largely, in favour of the hypothesis of long-run weak exogeneity; hence, in these cases we can confidently state that the relationship is not spurious. On the contrary, in all cases but one (Marche) where a positive coefficient was found the test is significant. Hence, these positive relationships are very likely to be spurious, and the variable safely excluded. Since in the single case of Marche it is likely to be acting as a proxy we excluded the variable from this equation as well.

The results of this specification search (Table 5A) are striking: all panel cointegration $p$-values are now close to, or even smaller than $1 \%$. The plots of the series and the FM-OLS estimates (Fig. 3) show that the models manage to capture the main trends as well as some local swings, both in the case of positive and negative trends. As expcted, an increase of the unemployment rate in the destination area, for a given level in the area of origin, discourages emigration. On the opposite, an increasing wage differential pushes emigration with very high coefficients especially in the dynamic North-Eastern regions of Trentino-Alto Adige and Friuli-Venezia Giulia: a $1 \%$ increases in wage differential increases the immigration by at least $5 \%$. The per capita consumption, which acts as a proxy of transfers, when included has always the expected negative sign, with coefficients very similar across destinations. Past emigration discourages new inflows.

The foreigner share (for which the long-run weak exogeneity hypothesis is now always largely accepted: see column $W_{f}$ in Table $5 \mathrm{~B}$ ) appears to have a negative effect on internal migration in the North-West (Piedmont-Val d'Aosta, Liguria and Lombardia) and in two of the four regions of the Center (Toscana and Lazio). No effect, on the other hand, is found in any of the fast-growing regions of the North-East. Altogether, we can conclude that, conditional on unemployment and wage differences, the share of foreigners matters: the higher it is, the smaller the native immigration flows relative to the destination labour force.

The picture that emerges is very clear. Foreign migrants increase the 
opportunity cost of moving to the former destination areas, North West (Piemonte, Lombardia, Liguria) and Tuscany, while do not play a significant role in the more recent destination area the North East and this rise the question of the direction of the causality. Do employers hire foreigners because internal migrants do not move anymore to the North West, or, rather, internal migrants stopped going to the North West because the foreign migrants reduced their job options? Since the cointegrating equation (12) describes an equilibrium, it is compatible with causality between the share of foreign workers and internal migration running in both directions: from the former to the latter, as assumed in our analysis, or vice versa. ${ }^{9}$ Keeping all possible caveats on the elusiveness of the concept of causality in mind, we can tackle the issue using the concept of Granger causality. Following Granger (1988), we estimate an error correction model (ECM) explaining the growth in the share of foreign workers with the lagged growth of all the other right-hand side variables of the model (12) and the lagged disequilibrium of internal migration:

$$
\begin{aligned}
\Delta f_{d t}= & \gamma_{0}+\gamma_{1}\left(\Delta w_{d t-1}-\Delta w_{h t-1}\right)+\gamma_{2}\left(\Delta u_{d t-1}-\Delta u_{h t-1}\right)+\gamma_{3} \Delta m_{d h t-1}+ \\
& \gamma_{4} \Delta c_{h t-1}+\gamma_{5} \Delta m s t_{d h, t-2}+\gamma_{6} E C M_{t-1}+v_{d h t}
\end{aligned}
$$

where

$E C M_{t}=m_{d h t}-\beta_{0}-\beta_{1}\left(w_{d t}-w_{h t}\right)-\beta_{2}\left(u_{d t}-u_{h t}\right)-\beta_{3} f_{d t}-\beta_{4} c_{h t}-\beta_{5} m s t_{d h, t-1}$.

The hypothesis that internal migration does not Granger cause the share of foreign workers conditional on the information set of equation (12) can be expressed as $H_{0}: \gamma_{3}=\gamma_{6}=0$. If this hypothesis holds neither the lagged growth nor lagged level (embedded in the ECM) of internal migration play any role in determining the current growth of the share of foreign workers.

As we can see from the column $G_{N C}$ in Table $5 \mathrm{~B}$ the $p$-values of this hypothesis are all very large (the smallest is 0.55 ): we can thus safely exclude an inverse causal link running from internal migration to the share of foreign workers.

Table $4 \mathrm{~A}$

Long-run trends in native immigration in the

Central-Northern Italian regions from South Italy, 1978-2001

\begin{tabular}{|c|c|c|c|c|}
\hline & \multicolumn{3}{|c|}{ Bootstrap $p$-values $\times 100$} \\
\hline & & simple & $F D B_{1}$ & $F D B_{2}$ \\
\hline Group $t$ & -3.79 & 32.4 & 46.1 & 43.5 \\
\hline Median $t$ & -4.58 & 8.8 & 15.4 & 12.3 \\
\hline
\end{tabular}

Panel Cointegration Tests - Unrestricted models

\footnotetext{
${ }^{9}$ Clearly, for cointegration to hold, one of the two causality links must exist.
} 
Table 4B

Long-run trends in native immigration in the

Central-Northern Italian regions from South Italy, 1978-2001

FM-OLS estimates - Unrestricted models

\begin{tabular}{lcccccc|cc}
\hline \hline Destination & $\theta$ & $u^{d}$ & $w^{d}$ & $f$ & $P m$ & $c^{h}$ & $W_{f}$ & $Z_{\alpha}$ \\
\cline { 2 - 9 } Piemonte- .A. & 7.23 & -0.99 & 0.43 & -0.37 & -0.16 & -0.87 & -0.91 & -27.99 \\
& {$[4.09]$} & {$[10.22]$} & {$[0.70]$} & {$[4.39]$} & {$[6.90]$} & {$[2.02]$} & {$[18.8]$} & \\
\cline { 2 - 9 } Lombardia & 12.93 & -0.52 & 0.75 & -0.11 & -0.04 & -1.39 & -0.61 & -25.68 \\
& {$[4.80]$} & {$[8.50]$} & {$[1.54]$} & {$[1.52]$} & {$[1.92]$} & {$[4.91]$} & {$[27.5]$} & \\
\hline Trentino-A. A. & 19.54 & -0.25 & 4.52 & 0.59 & 0.05 & -2.01 & 2.33 & -23.69 \\
& {$[1.62]$} & {$[1.78]$} & {$[3.77]$} & {$[1.11]$} & {$[0.81]$} & {$[1.64]$} & {$[1.7]$} & \\
\hline Veneto & 10.56 & -0.24 & 2.76 & 0.21 & -0.003 & -1.01 & -1.23 & -17.03 \\
& {$[2.53]$} & {$[2.29]$} & {$[4.14]$} & {$[2.24]$} & {$[0.10]$} & {$[2.27]$} & {$[11.8]$} & \\
\hline Friuli- V. G. & 16.86. & -0.24 & 1.09 & 0.19 & -0.17 & -1.68 & -1.61 & -20.83 \\
& {$[2.54]$} & {$[1.91]$} & {$[0.82]$} & {$[1.36]$} & {$[3.80]$} & {$[2.30]$} & {$[6.4]$} & \\
\hline Liguria & 18.03 & -1.05 & -3.04 & -0.11 & 0.05 & -1.99 & -0.65 & -21.26 \\
& {$[7.51]$} & {$[8.90]$} & {$[5.81]$} & {$[1.63]$} & {$[2.96]$} & {$[7.84]$} & {$[26.3]$} & \\
\hline Emilia-R. & 26.8 & -0.77 & 0.89 & 0.48 & -0.15 & 2.59 & 2.19 & -18.99 \\
& {$[3.84]$} & {$[6.32]$} & {$[0.89]$} & {$[3.65]$} & {$[3.36]$} & {$[3.61]$} & {$[2.2]$} & \\
\hline Toscana & -13.76 & -0.08 & 0.70 & -0.46 & -0.09 & 1.56 & 1.03 & -28.77 \\
& {$[3.16]$} & {$[0.65]$} & {$[0.96]$} & {$[4.12]$} & {$[3.09]$} & {$[3.42]$} & {$[15.9]$} & \\
\hline Umbria & -7.65 & -0.38 & -1.32 & -0.11 & -0.05 & 0.95 & 0.99 & -23.42 \\
& {$[2.66]$} & {$[3.18]$} & {$[1.85]$} & {$[2.73]$} & {$[2.43]$} & {$[2.92]$} & {$[17.0]$} & \\
\hline Marche & 14.20 & -1.26 & -1.16 & 0.24 & 0.05 & -1.53 & -1.00 & -23.27 \\
& {$[4.25]$} & {$[9.96]$} & {$[1.52]$} & {$[3.81]$} & {$[3.09]$} & {$[4.26]$} & {$[16.7]$} & \\
Lazio & 2.80 & -0.42 & 3.28 & -0.69 & 0.001 & -0.39 & 0.11 & -24.40 \\
& {$[0.31]$} & {$[0.98]$} & {$[1.22]$} & {$[1.41]$} & {$[0.02]$} & {$[0.44]$} & {$[45.6]$} & \\
\hline \hline
\end{tabular}

Dependent variable: immigrants from South Italy/destination labour force (log);

$\theta$ : constant;

$u^{d}: \log$ unemployment differential (destination-home);

$w^{d}: \log$ wage differential (destination-home);

$f:$ share of foreigners on labour force of destination area $(\log )$;

$P m$ : past migration;

$c^{h}$ : home per capita household consumption (log, 1995 prices);

$t$-statistics: in brackets;

$W_{f}: t$-test of long-run weak exogeneity of $f$ for the cointegrating coefficients;

$p$-value in brackets;

$Z_{\alpha}$ : Phillips' cointegration test 
Table 5A

Long-run trends in native immigration in the

Central-Northern Italian regions from South Italy, 1978-2001

Panel Cointegration Tests - Restricted models

\begin{tabular}{ccccc}
\hline \hline & \multicolumn{3}{c}{ Bootstrap $p$-values $\times 100$} \\
\cline { 3 - 5 } & & simple & $F D B_{1}$ & $F D B_{2}$ \\
\hline Group $t$ & -3.41 & 0.7 & 1.3 & 1.3 \\
\hline Median $t$ & -4.38 & 0.5 & 1.1 & 0.8 \\
\hline \hline
\end{tabular}

Model: equation (12) with zero restrictions (see

Table 5B);

Bootstrap: 1000 redrawings, block length: 4;

$F D B$ : Fast Double Bootstrap, type 1 and 2.

Table 5B

Long-run trends in native immigration in the

Central-Northern Italian regions from South Italy, 1978-2001

FM-OLS estimates - Restricted models

\begin{tabular}{|c|c|c|c|c|c|c|c|c|c|}
\hline Destination & $\theta$ & $u^{d}$ & $w^{d}$ & $f$ & $P m$ & $c^{h}$ & $W_{f}$ & $G_{N C}$ & $Z_{\alpha}$ \\
\hline Pidmonte-V. A. & $\begin{array}{c}-8.81 \\
{[3.52]}\end{array}$ & $\begin{array}{c}-1.01 \\
{[8.60]}\end{array}$ & - & $\begin{array}{l}-0.30 \\
{[2.97]}\end{array}$ & $\begin{array}{c}-0.14 \\
{[4.65]}\end{array}$ & $\begin{array}{c}-1.01 \\
{[1.94]}\end{array}$ & $\begin{array}{c}-0.11 \\
{[0.46]}\end{array}$ & $\begin{array}{l}0.26 \\
{[0.77]}\end{array}$ & -27.90 \\
\hline Lombardia & $\begin{array}{c}-0.26 \\
{[0.98]}\end{array}$ & $\begin{array}{c}-0.52 \\
{[8.50]}\end{array}$ & $\begin{array}{l}0.75 \\
{[1.54]}\end{array}$ & $\begin{array}{c}-0.11 \\
{[1.52]}\end{array}$ & $\begin{array}{c}-0.04 \\
{[1.92]}\end{array}$ & $\begin{array}{c}-1.39 \\
{[4.91]}\end{array}$ & $\begin{array}{c}-0.61 \\
{[0.28]}\end{array}$ & $\begin{array}{l}0.16 \\
{[0.85]}\end{array}$ & -25.68 \\
\hline Trentino-A. A. & $\begin{array}{l}4.10 \\
{[1.78]}\end{array}$ & - & $\begin{array}{l}5.28 \\
{[4.14]}\end{array}$ & - & - & $\begin{array}{c}-0.41 \\
{[1.54]}\end{array}$ & - & & -22.94 \\
\hline Veneto & $\begin{array}{c}1.02 \\
{[13.75]}\end{array}$ & - & $\begin{array}{l}3.63 \\
{[4.50]}\end{array}$ & - & $\begin{array}{l}-0.05 \\
{[1.12]}\end{array}$ & - & - & & -3.46 \\
\hline Friuli-V.G. & $\begin{array}{l}10.78 \\
{[4.52]} \\
\end{array}$ & - & $\begin{array}{l}6.69 \\
{[3.90]} \\
\end{array}$ & - & $\begin{array}{c}-0.18 \\
{[3.28]}\end{array}$ & $\begin{array}{c}-1.02 \\
{[3.71]}\end{array}$ & - & & -12.12 \\
\hline Liguria & $\begin{array}{c}-11.38 \\
{[2.81]}\end{array}$ & $\begin{array}{c}-0.71 \\
{[4.06]}\end{array}$ & - & $\begin{array}{c}-0.61 \\
{[8.50]}\end{array}$ & $\begin{array}{c}-1.28 \\
{[3.04]}\end{array}$ & - & $\begin{array}{c}-0.39 \\
{[0.35]}\end{array}$ & $\begin{array}{l}0.62 \\
{[0.55]}\end{array}$ & -20.94 \\
\hline Emilia-R. & $\begin{array}{l}1.54 \\
{[9.36]} \\
\end{array}$ & $\begin{array}{c}-0.32 \\
{[1.84]}\end{array}$ & $\begin{array}{l}3.33 \\
{[1.91]}\end{array}$ & - & $\begin{array}{c}-0.17 \\
{[2.67]}\end{array}$ & - & - & & -1.31 \\
\hline Tuscany & $\begin{array}{c}1.56 \\
{[13.40]}\end{array}$ & - & - & $\begin{array}{c}-0.05 \\
{[2.07]} \\
\end{array}$ & $\begin{array}{c}-0.09 \\
{[3.42]}\end{array}$ & - & $\begin{array}{c}-0.42 \\
{[0.34]}\end{array}$ & $\begin{array}{l}0.09 \\
{[0.91]}\end{array}$ & -7.66 \\
\hline Umbria & $\begin{array}{c}0.77 \\
{[16.69]}\end{array}$ & $\begin{array}{c}-0.63 \\
{[9.92]}\end{array}$ & - & - & - & - & - & & -4.40 \\
\hline Marche & $\begin{array}{l}0.24 \\
{[1.93]}\end{array}$ & $\begin{array}{c}-1.00 \\
{[8.25]}\end{array}$ & - & - & - & - & - & & -18.27 \\
\hline Lazio & $\begin{array}{c}-0.55 \\
{[0.72]}\end{array}$ & - & $\begin{array}{l}3.56 \\
{[1.39]}\end{array}$ & $\begin{array}{c}-0.72 \\
{[4.40]}\end{array}$ & - & - & $\begin{array}{c}-0.09 \\
{[0.46]}\end{array}$ & $\begin{array}{l}0.15 \\
{[0.86]}\end{array}$ & -23.31 \\
\hline
\end{tabular}

Dependent variable: immigrants from South Italy/destination labour force (log);

$G_{N C}: F$-test of $H_{0}$ : internal migrations do not Granger cause $f ; p$-value in brackets;

all other definitions and abbreviations: see table 4B 

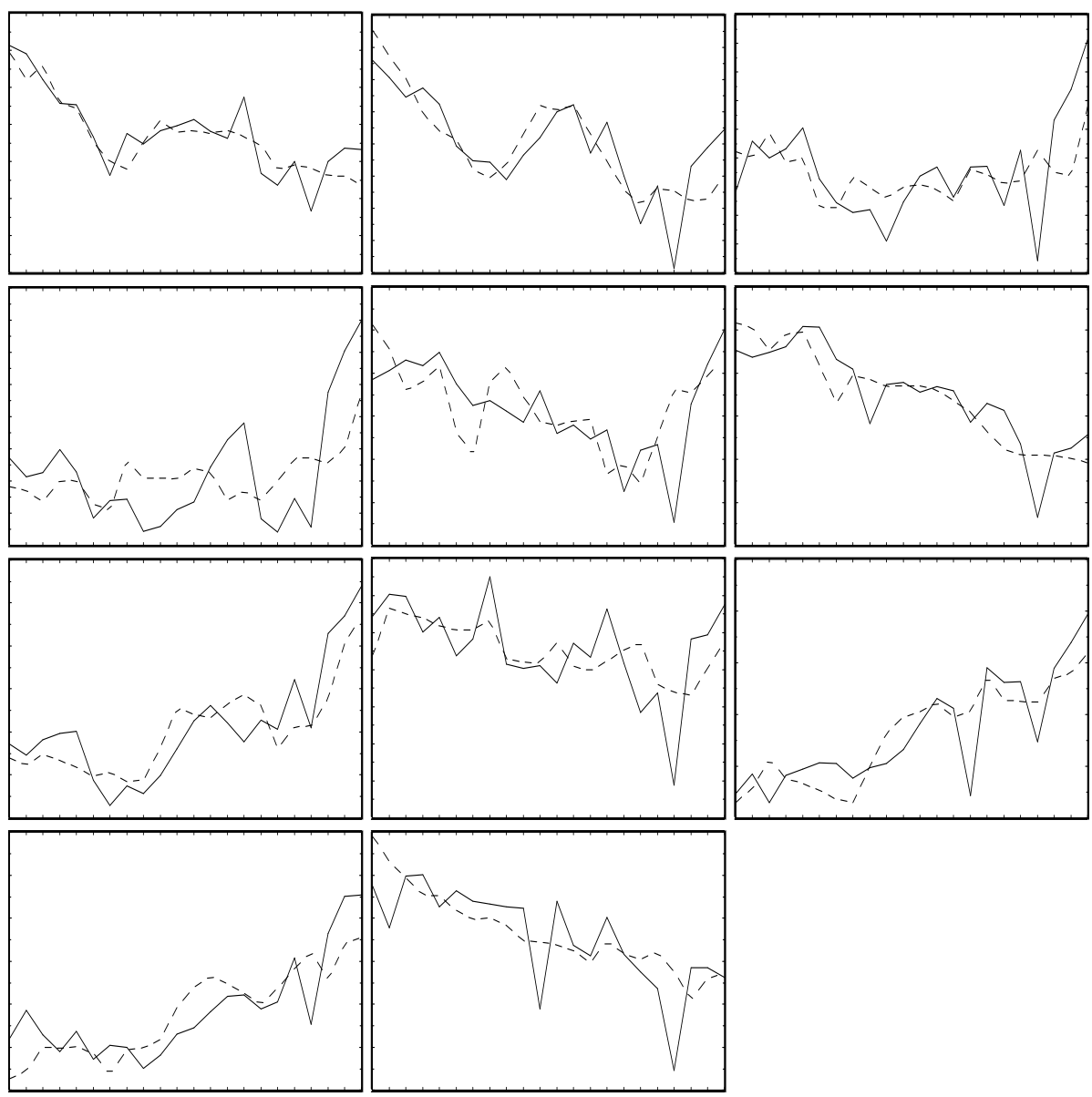

Figure 3: Native immigrants from South Italy on labour force (logs, solid line) and FM-OLS estimates (dashed line), 1978-2001. Left to right and top to bottom: Piemonte and Val d'Aosta, Lombardia, Trentino-Alto Adige; Veneto, Friuli-Venezia Giulia, Liguria; Emilia-Romagna, Toscana, Umbria; Marche, Lazio. 


\section{Conclusions}

In this paper we have considered three channels by which the immigration of foreigners can affect the internal migration of natives in Italy: First, by reducing the wage difference between the destination and the sending region, second, by reducing the difference in employment opportunities in the destination and sending regions, and, third, directly by affecting the utility of natives. Note that the share of foreigners affects utility in several ways, e.g. through housing prices, congestion, criminality or simply xenophobia. Our estimation results suggest that all three channels matter: Internal migration of natives from the South to the North in Italy is driven both by economic factors such as wage and unemployment differences as well as by the foreigner share in the destination region. Moreover, we find evidence that the foreigner share in the destination region Granger causes internal migration rather than the other way round.

Thus, the traditional empirical literature (e.g. Hatton and Tani, 2005) which focusses on the emigration of natives from the destination region may miss the key point how immigration of foreigners affect domestic labour supply in the destination region. Considering all three groups - foreigners, natives at the destination and natives in other regions - may thus contribute to a better understanding of the labour market effects of international migration. Note that foreign workers may be complementary to local natives in the destination areas (see Gavosto, Venturini, Villosio, 1999; Venturini, Villosio 2006, for evidence), but compete with potential native migrants from other areas of the country.

An interesting point in this context is that Barba, Bertola and Sembenelli (2006) find that firms that hire migrants have a lower rate of direct investment abroad, while much higher foreign direct investment shares are found for firms which do not hire foreign workers (in fact, the opening of the East European countries has created new incentives for international capital movements, lowering those for decentralizing to South Italy). Hence, foreign immigrants complement local native workers rather than to replace them. Thus, foreign immigrants are far from "stealing natives' jobs", instead they help keeping investment and production activities in the immigration areas. However, the picture looks less favourable if we consider the impact on regional imbalances in the destination countries: The immigration of foreigners can aggravate internal imbalances both by reducing domestic migration from the poorer to the more prosperous regions as well as by reducing investment from rich to poor regions.

Altogether, our findings suggest that the area approach to assess the labour market impact of international migration might by by ill-suited if we do not consider other currents which equilibrate the effects of immigration across regions. One of these channels is the replacement of domestic migration from poor to rich regions through the immigration of foreigners. Our 
analysis suggests that the impact of foreign immigration on domestic migration is far from irrelevant in the Italian case. To examine the implications for labour markets is an important issue for future research.

\section{Appendix Data Sources and definitions}

\section{Native Immigrants}

Data on in internal migration flows are collected by Istat (the national statistical agency) from the local Registrars' Offices. Since Italian residents are required by law to register in the place where they live (and, further, actually need to in order to have full access to the national health services and other benefits) these data are likely to represent accurately, even if not very timely, migration flows. Data for male migrants (primary workers) are used as a dependent variable, and for male and female flows in the construction of the proxy for the chain variable.

\section{Wages}

Regional series for the annual wage rate are derived from the WHIP (Work Histories Italian Panel) archive based upon social security data. The annual wage is defined as the total amount of the earnings received monthly by the employees (basic wage, cost-of-living allowance, residual fees, overtime payments), plus the total amount of the non-monthly wage (back pay, bonuses, supplements holiday pay, sick pay). It is the reference values used to calculate social security and insurance contributions paid by the firm, the social security burden of the employee and, if applicable, tax relief applied to employment. Therefore, this represents the annual compensation received by the employee net of the social security and health benefit contributions paid by the firm, but gross of those due by the employee.

\section{Unemployment Rate and Labour Force}

Both included in the standard labour force survey data published by Istat.

\section{Foreign Immigrants}

Regional data on residence permits issued are collected by the Ministry of the Interior and revised by Istat. A serious problem of these series is the failure to exclude expired permits until 1991, which causes $(i)$ a growing, positive bias up to that year, and $(i i)$, a strong negative structural break in 1992. To obtain a series representing more accurately the actual number of foreign workers present in the local labour markets we decided to smooth the observations for the period 1985-1995 using a kernel regression on a linear time trend. 


\section{References}

Amuedo-Dorantes C, De la Rica S. Immigrants' Responsiveness to labour Market Conditions and Its Implications on Regional Disparities: Evidence from Spain. IZA D.P. 1557; 2005.

Attanasio O, Padoa-Schioppa F. Regional inequalities, migration and mismatch in Italy 1960-86. In: Padoa-Schioppa F (Ed), Mismatch and labor mobility. Cambridge University Press: Cambridge (UK); 1991.

Barba Navaretti G, Bertola G, Sembenelli A. Offshoring and Immigrant Employment: Firm-level Theory and Evidence. Università di Milano DEAS Working Paper No 09; 2006.

Borjas G, Freeman R, Katz R. How much Do Immigration and trade Affect Labor Market Outcomes? Brookings Papers on Economic Activity 1997;1-67.

Borjas G. The demand curve is downward sloping: re-examining the impact of immigration on the labor market. Quarterly Journal of Economics $2003 ; 118 ; 1335-1374$.

Boswijk HP. Cointegration, Identification and Exogeneity. Inference in Structural Error Correction Models. Tinbergen Institute: Amsterdam (NL), 1992.

Boswijk HP. Efficient Inference on Cointegration Parameters in Structural Error Correction Models. Journal of Econometrics 1995;69; 133-158.

Card D. The Impact of Mariel Boatlift on the Miami Labor Market. Industrial and Labour Relations Review 1990; 43; 245-57.

Card D. Immigrant Inflows, native Outflows and the Local labor Market Impacts of Immigration. Journal of Labour Economics 2001; 19; 22-64.

Card D. Is the New Migration Really So Bad? Economic Journal 2005; 115; F300-F323.

Card D, Di Nardo JE. Do Immigrants Inflows lead to Native outflows? American Economic Review 2000; 90; 360-73.

Carrington W, De Lima P. The impact of 1970's Repatriates from Africa on the Portuguise Labour Market. Industrial and Labour Relations Review 1996; 49; 330-347.

Clark X, Hatton TJ, Williamson JG. Where do U.S. immigrants come from, and why? NBER Working Paper No. 8998; 2002. 
Davidson R, MacKinnon JG. Improving the Reliability of Bootstrap Tests. Queen's University Institute for Economic Research Discussion Paper No. 995; 2000.

Del Boca D, Venturini A. (2005) Italian Migration. In Zimmermann K. (Ed), European Migration. Oxford University Press: Oxford (UK); 2005. p. 303-336.

Dickey DA, Pantula SG. Determining the order of differencing in autoregressive processes. Journal of Business and Economic Statistics 1987; $5 ; 455-61$.

Di Iorio F, Fachin S. A Note on the Estimation of Long-Run Relationships in Dependent Cointegrated Panels. MRPA WP n. 12053; 2008. http://mpra.ub.uni-muenchen.de/12053/

Dustmann C, Fabbri F, Preston I, Wadsworth J. The Local Labour Market Effects of Migration in the UK. Home Office Online Report 06/03; 2003.

Fachin, S. Long-Run Trends in Internal Migrations in Italy: a Study in Panel Cointegration with Dependent Units. Journal of Applied Econometrics 2007; 22; 401-428.

Faini R, Galli G, Gennari P, Rossi F. An empirical puzzle: falling migration and growing unemployment differentials among Italian regions. European Economic Review 1997; 41; 571-579.

Filer R. (1992) The impact of immigrant arrivals on migratory patterns of native workers. In Borjas GJ, Freeman RB. (Eds.) Immigration and the Work Force: Economic Consequences for the United States and Source areas. University of Chicago Press: Chicago (USA); 1992.

Eurostat European Labour Force Survey. Eurostat: Luxembourg; 2008.

Gavosto A, Venturini A, Villosio C. Do Immigrants Compete with Natives? Labour 1999; 13; 603-622.

Granger CWJ Some recent development in a concept of causality. Journal of Econometrics 1988; 39; 199-211.

Groen JJJ, Kleibergen F. Likelihood-based cointegration analysis in panels of vector error-correction models. Journal of Business and Economic Statistics 2003; 21; 295-318.

Haisken-De New JP, Zimmermann K. (1999) Wage and Mobility Effects of Trade and Migration. In Dewatripont M, Sapir A, Sekkat K. (Eds.) Trade and Jobs in Europe, Much Ado about Nothing? Oxford University Press: Oxford (UK); 1999; p. 139-160. 
Hatton TJ. A model of U.K. migration, 1870-1913. Review of Economics and Statistics 1995; 77; 407-415.

Hatton TJ. Explaining Trends in UK Immigration. CEPR Discussion Paper No. 4019; 2003

Hatton,TJ, Tani M. Immigration and inter-regional mobility in the UK, 1982-2000. The Economic Journal; 2005;11; F342-F358.

Hunt J. The Impact of the 1962 Repatriates from Algeria on the French Labor Market. Industrial and Labour Relations Review 1992; 45; 556572 .

Im KS, Pesaran MH, Shin Y. Testing for unit roots in heterogenous panels. Journal of Econometrics 2003; 115; 53-74.

Longhi S, Nijkamp P, Poot J. A Meta-Analytic Assessment of the Effect of Immigration on Wages. Journal of Economic Surveys 2005; 19; 451-477.

Longhi S, Nijkamp P, Poot J. Spatial Heterogeneity And The Wage Curve RevisitedJournal of Regional Science 2006; 46; 707-731.

Longhi S, Nijkamp P, Poot J. Meta-Analysis of Empirical Evidence on the Labour Market Impacts of Immigration, IZA D.P. No 3418; 2008

Murat M, Paba S. International Migration, Outsourcing, and Italian Industrial Districts. Materiali di discussione n. 464, Dipartimento di Economia, Università di Modena e Reggio Emilia; 2004.

Moon HR. A note on fully-modified estimation of seemingly unrelated regressions models with integrated regressors. Economics Letters 1999; $65 ; 25-31$.

Ottaviano GM, Peri G. Rethinking the gains from Immigration: Theory and Evidence from the U.S., NBER Working Paper No 12497; 2006

Pedroni P. Cross Sectional Dependence in Cointegration Tests of Purchasing Power Parity in Panels. Indiana University Working Paper; 1997.

Pedroni P. Fully modified OLS for heterogeneous cointegrated panels. Advances in Econometrics: Nonstationary Panels, Panel Cointegration and Dynamic Panels 2000; 15; 93-130.

Pedroni P. Purchasing power parity tests in cointegrated panelsReview of Economics and Statistics; 2001; 83; 1371-1375.

Pesaran HM, Smith R. Estimating Long Run Relationships from Dynamic Heterogeneous Panels. Journal of Econometrics; 1995; 68; 79-114. 
Pesaran MH. A simple panel unit root test in the presence of cross-section dependence. Journal of Applied Econometrics; 2007; 22; 265-312.

Phillips PCB, Hansen BE. Statistical inference in instrumental variables regression with I(1) processes. Review of Economic Studies; 1990; 57; $99-125$.

Venturini A. Post-War Migration in Southern Europe. An Economic Approach. Cambridge University Press: Cambridge (UK); 2004

Venturini A, Villosio C. Labour Market Effects of Immigration into Italy: An Empirical Analysis. International Labour Review 2006; 145; 91118.

Winkelmann R, Zimmermann KF. Ageing, migration and labour mobility. In Johnson PA and Zimmermann KF (Eds) Labour Markets in an Ageing Europe. Cambridge University Press, Cambridge (UK); 1993. p. $255-283$. 